\title{
George Santayana and emotional distance in philosophy and politics ${ }^{1}$
}

\author{
John Christian LAURSEN \& Ramón Román AlCALÁ
}

Recibido: 17 de diciembre de 2013

Aceptado: 9 de julio de 2014

\begin{abstract}
George Santayana (1863-1952) appears emotionally distant and personally uncommitted in many of his writings. In what may have been a related phenomenon, he does not seem to have committed to any school of philosophy, but rather to draw from many of the available schools when it suited him. In this article, we assess his constantly changing use of different philosophies and its implications for both philosophy and politics.
\end{abstract}

Keywords: Santayana, Scepticism, Nihilism, Epicureanism, Materialism, Cynicism, Spinozism, Political Life.

Many readers have remarked upon the emotional distance or lack of commitment in many of the writings of George Santayana (1863-1952). Ever the critic, he rarely stakes his own claims and often seems quite detached from the issues he is writing about. We have here a case study of the importance of the emotional commitment of the philosopher or political thinker. What difference does it make if a thinker is hot or cold, outgoing or reserved, fully committed or wanly detached? A special feature of this case is that although most of his work was philosophy or literature, Santayana also wrote a major book about politics, so we have the opportunity to observe the effects of his general lack of emotional involvement in his political thought as well.

Emotional distance, lack of commitment, lack of involvement, reserve, and detachment are not customary technical concepts in the study of the works of important philosophers, so we are exploring a relatively new area in the history of

\footnotetext{
1 Este artículo se inscribe en el marco del Proyecto de Investigación I+D+i FFI2012-32989 sobre el escepticismo, financiado por el Ministerio de Economía y Competitividad.
} 
philosophy. We are not qualified to use these terms in any technical psychological sense. We use them only in the common sense meaning that any reader will recognize, and we hope that the meanings and family resemblances among this cluster of ideas will emerge from our treatment. They bring out one dimension of philosophy as something lived and related to the philosopher's personality that has been emphasized in some work on the history of philosophy of the last several decades. ${ }^{2}$

In conversation with a biographer, Santayana described his position as "like... the ancient Cynics or Sceptics, with a little Epicureanism to soften it". ${ }^{3}$ We take this and other self-descriptions of Santayana as warrant for understanding him in terms of several ancient (and modern) schools, sometimes at the same time and sometimes alternatively. It is also the case that Santayana used the vocabulary of philosophy in his own idiosyncratic way. He did not feel bound by the meanings attributed to philosophical words throughout the history of philosophy. It is a mistake to assume that his usage is the same or similar to the vocabulary current in contemporary philosophy. Rather, one must compare and contrast in order to distinguish his usage from traditional and contemporary usage. We are going to claim that he used the word scepticism variously for thoroughly sceptical scepticism, for dogmatic scepticism, and for nihilism; and that he used the term animal faith variously for Epicureanism, materialism, Spinozism, and cynicism. Analyzing his meanings will help us contribute to the inventory and classification of the philosophical families of these schools, and of their influence on political thought.

Santayana wrote a great deal and thus a full analysis of his personality and philosophy would require a book-length analysis of all of his work. To keep this article manageable we will have to center our analysis on just a few of his works in order to document in sufficient detail the connections between what we are calling his emotional distance and his philosophical and political ideas. Our chief text will be Scepticism and Animal Faith (1923), considered by many to be the epitome of his mature philosophy. ${ }_{4}^{4}$ And for the politics, we will rely mostly on Dominations and Powers: Reflections on Liberty, Society, and Government (1951), published when Santayana was 88 years old. ${ }^{5}$ We will also draw where helpful on his autobiography, letters, and some of his other works.

It is also the case that Santayana is something of a moving target. Philosophy was a process of discovery and reflection for him, and his thought could evolve inside any one book, let alone between books. Nevertheless, we think a core substance

\footnotetext{
2 Hadot (1995), Nehamas (1998), and, on Santayana, Moreno (2007).

${ }^{3}$ Lind (1962), pp. 24, 15. And if there are any doubts that he understood himself in ancient philosophical-political terms, he also told Lind "I was morally independent until I found my masters in the ancients", p. 170.

4 Santayana (1923). Hereafter cited in the text with the letters SF.

5 Santayana (1951). Hereafter cited in the text with the letters DP.
} 
and attitude can be identified, and that is what we try to do here. From early on in his career, we see a constant reserve, diffidence, and detachment which we are calling emotional distance in philosophy.

\section{Scepticism and distance}

We can start with the point that almost all authors have called Santayana a sceptic. 6 But what does that mean? In keeping with his reserve, Santayana often writes in Scepticism and Animal Faith of "a true sceptic..." (SF4) or "a thorough sceptic..." (SF5) or asserts that "the sceptic thinks himself shrewd..." (SF8) without admitting that this might be his own position. Often he attacks scepticism for going too far, as we shall see below. But on rare occasions he refers to "the scepticism I am defending" (SF49) and claims that "I have imitated the Greek sceptics" (SF308). He could be describing himself when he asserts that "they turned their scepticism into an expression of personal dignity and an argument for detachment" (SF308). Let us consider what the latter could mean.

Although most philosophers know that scepticism has been the label for a school or schools of thought since the $5^{\text {th }}$ century B.C., not all of those who use the word know or care much about the tradition, and it has often been used in idiosyncratic ways. Even the ancient Greeks recognized that the word was understood in different ways at different times and for different purposes. Santayana is both a part of the tradition and no exception to the rule that many members of the tradition did not pay careful attention to their place in its history. He tried to place others where they belonged: "Transcendental criticism in the hands of Kant and his followers was a sceptical instrument used by persons who were not sceptics" because they made "many uncritical assumptions, such as... that the notions of nature, history, or mind which they led many people to adopt were the right or standard notions on these subjects, and that it was glorious, rather than ignominious or sophistical, to build on these principles an encyclopedia of false sciences and to call it knowledge" (SF6). A "true sceptic", he wrote, "will begin by throwing over all those academic conventions as so much confessed fiction" (SF4). But, as we shall see, this did not mean that he did much to situate himself within the tradition of persons who were sceptics.

What others have labelled scepticism in Santayana may be rather a sort of distancing from the world and from other people, a detachment or unwillingness to take it seriously and take it to heart. This distancing from the world began relatively early, if we may trust his own account. As he tells it in Persons and Places, at the

\footnotetext{
${ }^{6}$ E.g. McCormick (1987), p. xiv, 3, etc. There is no indication that McCormick knew much about the traditions of scepticism.
} 
age of 30 he began a slow but inexorable withdrawal from the world, a gradual and phlegmatic separating of himself from everything. ${ }^{7} \mathrm{He}$ called this his "metanoia", a philosophical, religious, psychological, and social catharsis that replaced his relationships with the real world with distancing and disillusionment (PP423, 427). $\mathrm{He}$ explored the idea that "a perfect love is founded on despair" (PP428-9). In a letter, he wrote that "my philosophy has always been that disillusion is the only safe foundation for happiness". 8 The eventual consequence of this would be his resignation from Harvard, and his peripatetic, uncommitted, unrooted life in England, France, and Italy. As he put it, he would live in the world of ideas, in what he later called the "Realms of Being". As his poetry reflected, his withdrawal into the ideal and eternal echoed of Plato and Platonism. ${ }^{9}$

The expected social life and morals of a Bostonian and Spaniard of the elite of the late nineteenth and early twentieth centuries demanded worldly success and religious solidarity which predetermined a sort of consensus of self-satisfaction and satisfaction with the things around them of the elite. Santayana was dissatisfied with this uncritical optimism, and affirmed to the contrary that our mere existence is already a big risk, always subject to chance and containing as much risk of failure as of success. Whereas in Boston people focused only on moving forward and winning, Santayana wanted to know where he was going and what was the purpose before, as he put it, picking up his weapons (PP410).

The philosophy of success that ruled in the young and shining America of his day ran against the feelings and character of our philosopher. 10 The point of departure of his philosophical project was sceptical in the sense of reacting viscerally against the dogmas of the day which seemed to capture so completely the most active minds of the time. In part, this was because he saw philosophy as like a jungle, where "one tree strangles another, and luxuriance itself is murderous" (SF8). Thus, Santayana saw his objective as to revitalize for the twentieth century a certain sceptical attitude with respect to the wide and varied catalogue of dogmatic theories available in the splendid philosophical bazaar of the time.11

\footnotetext{
${ }^{7}$ Cf. Santayana (1986), pp. 417-429. Hereafter cited in the text with the letters PP.

Santayana writes that three events led to his withdrawal: the death of his "last real friend", Warwick Potter; the death of his father, which "helped to disintoxicate my mind"; and the marriage of his sister, Susana. Santayana (1986), pp. 423-425.

8 Santayana (2002), vol. 5, II, p. 233.

${ }^{9}$ See the analysis of his poem, "Resignation" (1888), later revised as "The Pessimist" in "Six Wise Fools", in García Martín (2002), p. 135.

${ }^{10}$ Santayana was a devastating crític of the self-proclaimed moral and intellectual elites of the United States, writing that they "seemed to be uniform: earnest, meager, vague, scattered, and hopeful" (PP 411). The admirable qualities here, "earnest" and "hopeful", are undercut by their association with other qualities that make the whole picture look rather pitiful. Cf. Santayana (2009), pp. 39-50.

11 Santayana always opposed the most influential philosophy of his day: the idealism of Kant, Fichte, Schelling, and Hegel which dominated in the universities of the United States and Great Britain during his years at Harvard. See Seaton (2009), p. xiii.
} 
A careful reading of his works helps us clarify his understanding of scepticism. We believe that his scepticism is more aesthetic than epistemological, more gestural than profound, and more light-hearted and Epicurean than serious and Pyrrhonian. Let us start with a comparison with the Greek sceptical traditions.

\section{Greek Scepticism of the Presocratic and Academic Traditions}

It is customary to say that in its origins Greek scepticism proposed a radical cure, using a medical analogy, for excessive claims of knowledge and truth. As a sort of purge, scepticism seeks to cure the arrogance of the dogmatic thinkers and humble the purveyors of truth. It is an attitude of criticism that becomes spontaneous and natural, accompanying all thought, and thus a way of life (agoge) rather than a doctrine. 12 And perhaps it is precisely for that reason that some sceptics do not even realize that they are part of a tradition of thought.

Although the history of scepticism as a philosophical (or anti-philosophical) tradition is complex and often obscure, two basic schools have been widely accepted. Academic scepticism derived more or less straightforwardly from Plato's Academy, and can be traced through his successors in that institution. ${ }^{13}$ The more radical Pyrrhonism has a more unsure pedigree that associates its founder, Pyrrho of Elis, with Aenesidemus, Sextus Empiricus, and Saturninus Citenas. This school may have been a reconstruction by Aenesidemus mainly in order to attack the moderation of the Academy. ${ }^{14}$

At the beginning of his most famous work, Outlines of Pyrrhonism, Sextus Empiricus distinguished three philosophical systems: the dogmatic, the Academic, and the sceptical. The dogmatists declared that they had found the truth (although each had found a different truth). The Academics and sceptics could be distinguished because the former declared the truth inapprehensible while the latter suspended judgment about its apprehensibility while continuing to look for it. 15 Thus, as Aulus Gellius put it, the Academics were a sort of dogmatic sceptics since they took the proposition that "nothing can be comprehended" as a truth, while the true sceptics, also known as the Pyrrhonians, suspended judgment even about that. ${ }^{16}$ It is safe to

\footnotetext{
12 The Pyrrhonist accepts no doctrine, but rather lives without strong beliefs (adóxastos), yet nevertheless may be happy. See Román (2005), pp. 35-51.

13 The Platonic Academy can be reconstructed from Plato through Speussipus to Xenocrates, Polemon, Crates of Athens, Crantor, Arcesilaus, Carneades, Clitomachus, Metrodorus of Stratonica, Philo of Larissa, and Antiochus of Ascalon. See Román (2007).

14 On the late invention of Pyrrhonism as a school, see Román (2012), pp. 111-130.

15 Sextus Empiricus (1933), p. 3.

16 "But although the Pyrrhonians and the Academics express themselves very much alike about these matters, yet they are thought to differ from each other both in certain other respects and especially for
} 
say that Santayana's philosophy contains each of these elements. Some of his assertions are dogmatic, some follow the Academic path of declaring things unknowable, and some come closer to suspending judgment while continuing to investigate. But the last of these are just gestures in that direction, and we argue below that on the whole Santayana cannot be characterized as a Pyrrhonian sceptic. Rather, he puts various elements together to create his own idiosyncratic scepticism. ${ }^{17}$

As already mentioned, scepticism could be defended against charges that it undermined itself if it were conceived of as not a doctrine subject to such undermining, but as an activity or way of life. 18 It was a way of life with three important features: 1 . it could be incorporated into ordinary, daily life; 2 . it provided solutions to the problem of knowledge: living by good reasons or probabilities in the absence of knowledge (Academic scepticism) or suspending judgment about it (Pyrrhonian scepticism); and 3. in the case of the Pyrrhonists, the aphasia, or speechlessness, that suspension of judgment induces and ataraxia, or the tranquility that follows it, may lead us to happiness. The last of these, also translated as freedom from disturbance, was the common goal of the stoics, Epicureans, and sceptics. Not much has been written about exactly what the tranquil life of the sceptic would be like. We suggest that Santayana's writings can be understood as one philosopher's path to ataraxia.

Santayana starts with the constant and continual experience of errors and perplexities in the history of philosophy, and sees some sort of scepticism as necessary for anyone who does not want to appear ridiculous and negligent in philosophy. This scepticism, which has a correcting and repairing function (SF69-70), most likely can be traced to the Greek sources, but he does not cite them as we might expect. He does not mention Arcesilaus, Carneades, Clitomachus, or Philo from the Academic school, nor Pyrrho, Timon, Aenesidemus, or Sextus from the Pyrrhonians.

Instead, the language Santayana uses to define scepticism, sometimes rather aggressively at odds with the traditions of scepticism, is of an unusual variety and aesthetic beauty. For example, he describes scepticism as a "form of belief", "a suspicion of error about facts", and claims to use it to "clear my mind of illusion, even at the price of intellectual suicide" (SF8,10). "Scepticism is not sleep", it "is an exercise, not a life", it "is the chastity of the intellect" (SF42,69). His examples are many and varied, bringing us to one of the main problems in understanding

this reason - because the Academics do, as it were, "comprehend" the very fact that nothing can be comprehended, while the Pyrrhonians assert that not even that can by any means be regarded as true, because nothing is regarded as true" (Aulus Gellius (1927), vol. II, p. 313.

${ }^{17}$ Santayana was not alone in inventing his own scepticism. His contemporary Michael Oakeshott also paid very little attention to the traditions and developed his own form. See Laursen (2005), pp. 37-55, esp. pp. 40-41.

18 See Laursen (2004), pp. 201-23 and Laursen (2005), pp. 167-188. 
Santayana: his style. The fact that he is a brilliant and creative writer means that he belongs to the class of philosophers who create original ideas and concepts by their sparkling use of language alone. This can have the downside of the writer paying little or no attention to the history and development of the ideas and concepts he puts to his own use. If, on the one hand, an excess of attention to tradition might asphyxiate creativity and originality, on the other hand forgetting all connection with it may lead to a sort of hyperventilation such that the philosopher tries to fill in too much that is already there and in the process faints from the exertion. Abandoning the tradition may save the philosopher from having to admit that some of his assumptions may not be justified, but it also leads to a loss of the terminological precision that a tradition can provide. As has been said, the medium and the message are inseparable, and sometimes the substance of the work is hard to find behind the brilliant style in which it is expressed. 19

The foregoing means that some of the time when Santayana refers to scepticism he is making no reference to the recognized Greek sceptics, nor for that matter to later thinkers generally recognized as sceptics. He also identifies as sceptics or precursors of scepticism many figures who may have pioneered some aspect of scepticism but who are generally better understood as dogmatists or philosophers who think they have arrived at truths. Citing Parmenides, Democritus, Gorgias, Protagoras, and the sophists in general, Santayana moves paradoxically between contrary positions, variously tending without wishing to toward an inevitable objectivism or naturalism, and then implying without intending it an absolute subjectivism and nihilism (to which we will return below). ${ }^{20}$

There were definite limits to Santayana's scepticism. He claimed to "push scepticism as far as I logically can" (SF10), but in fact he pulled back from it. In an attempt to undermine scepticism as suspension of belief, he asserted that "scepticism is accordingly a form of belief" and that "dogma cannot be abandoned" (SF8). In a reductio ad absurdum, he claimed that scepticism "will lead me to deny existence to any datum, whatever it may be" (SF35); "scepticism may thus be carried to the point of denying change and memory, and the reality of all facts" (SF40); and the strongest of all, "nothing given exists" (SF42). But of course these are all dog-

\footnotetext{
${ }^{19}$ McClay (2009), p. 123. Ignacio Izuzquiza ties together Santayana's concern with form with his aesthetic conception of philosophy in Izuzquiza (1989), p. 17. Alfonso Larrea García speaks of an intricate rhetorical code that pushes Santayana's prose toward the poetic in Larrea (2013), pp. 182-211. 20 Lachs (1988) affirms that "Santayana was deeply attracted to the objectivistic and naturalistic starting point of the Greeks" and "there is reason to believe that he wished to bypass and disregard the entire skeptical tradition" (p. 30), but Lachs does not seem to have much knowledge of the ancient sceptics: perhaps they fall under his description of pre-Cartesian sceptics as "heretics to be dealt with or oddities to deride" (p. 28). In any case, he did not take seriously Santayana's claim to draw from the cynics, sceptics, and Epicureans (see note 41 below). On subjectivism and objectivism, see Calogero (1932), pp. 247-251 and Dupréel (1948), pp. 68-70.
} 
matic claims, and would not have been accepted by the Greek sceptics, who would suspend judgment about them. In spite of his distancing from so many things, he seems to have genuinely cared about not taking scepticism as far as the collapse of philosophy. The ancient sceptics were not so genteel; they do not seem to have cared if philosophy was undermined. They could live without it.

\section{Pyrrhonism, Academic skepticism, dogmatism}

Let us evaluate Santayana's philosophy in the terms of Sextus Empiricus's three classes of philosophy. We shall start, in reverse order, with Pyrrhonism. There are echoes of the Pyrrhonists in some of his arguments. For example, when he observes that "complete scepticism is accordingly not inconsistent with animal faith", he explains that "I may yield to the suasion of instinct, and practice the arts with a humble confidence... [and] what guides me is not illusion but habit" (SF105). These two points read like they were taken from Sextus Empiricus's list of the four rules by which the Pyrrhonist lives in the absence of truths: "the guidance of nature,... the constraint of the passions,... the tradition of laws and traditions.. and instruction in the arts". 21 When he adds that "the intuitions which accompany habit are signs..." and that he regards "the images of sense and science" as "graphic symbols for home and for the way there" (SF105-106), he sounds like he is relying on Sextus's explanation of the "associative" or "commemorative" signs by which the sceptic lives: they do not tell us anything about reality or truth, as "indicative" signs are expected to do, but they do get us home. 22

Nevertheless, these gestures toward Pyrrhonism do not make Santayana a Pyrrhonist. Perhaps the strongest argument for ruling out the label of Pyrrhonism is his naturalism. As he put it, "in natural philosophy I am a decided materialist -apparently the only one living" (SFvii), and that naturalism underlies many of his arguments. Yet Pyrrhonists cannot be naturalists. In a classic article Sullivan asserted that Santayana's scepticism was founded on the same basis as the ancient sceptics, on the conviction that nothing is certain. ${ }^{23}$ But he adds that in rejecting knowledge the sceptics did not reject the natural world, but rather accepted it in its majesty and inscrutableness, affirming that "A sceptic is necessarily a naturalist". 24 No

\footnotetext{
21 Sextus Empiricus (1933), p. 17.

22 Sextus Empiricus (1935), pp. 319, 339-343.

23 Sullivan (1951), p. 86.

24 "The Sceptics in denying knowledge did not deny nature; by implication they asserted her Sphinxlike majesty. Ignorance is not ignorance, if of nothing, and in their absolute scepticism the Pyrrhonists saluted what they could not embrace, a nature independent of them, a power vast and inscrutable": Sullivan (1951), p. 86.
} 
sceptic of the ancient schools would say anything like that. They lived in a world of appearances, with no claims to knowledge about the nature behind them.

Let us explain why Pyrrhonism is not a naturalism. Eusebius reported that Pyrrho's "pupil Timon says that whoever wants to be happy must consider these three questions: first, how are things by nature? Secondly, what attitude should we adopt towards them? Thirdly, what will be the outcome for those who have this attitude? According to Timon, Pyrrho declared that things are equally indifferent (adiáphora), unmeasurable (astáthmeta) and inarbitrable (anepíkrita)."25 Timon began with the problem of how to achieve happiness, and the answer came from the theory of knowledge. The intention was predominantly ethical, and the goal was ataraxia or tranquility. ${ }^{26}$ Now, there are several ways of understanding this declaration. One is that Pyrrho meant that nature really is indifferent, unmeasurable, and inarbitrable. On this account, the achievement of ataraxia requires an answer to questions about nature and whether it can be determined and known. Love of knowledge and the drive to know are necessary and the only route to happiness. But there cannot be much of a naturalism because, in Pyrrho's judgment, nature is "equally indifferent, unmeasurable, and inarbitrable": we can know nothing about it beyond this.

On a second interpretation Pyrrho provides a theory of the limits of our ability to know anything about the world. If we cannot know anything, even if the world might be measurable and arbitrable by others, we can say nothing at all about it that will be either true or false. Thus, we must be, as Timon put it, "undogmatic and uncommitted and unswayed, saying of each and every thing, that it is no more than it is not, or both is and is not, or neither is nor is not". ${ }^{27}$ On this reading, naturalism would consist of only the statement that we cannot understand nature. Yet a theory of naturalism is expected to tell us more, and provide us with guidance for living.

There is also a reading of the foregoing passage that holds that Pyrrho is not really claiming anything about nature or about our abilities. Read through the lens of Sextus Empiricus's later elaborations, Pyrrho is only saying that things seem to be indifferent, unmeasurable, and inarbitrable, and that it is not worth any more trouble trying to sort them out. This is not, then, a theory about nature, but rather an eschewing of the need to know anything about nature. It is an anti-philosophical way of living with the world, more thoroughly sceptical than any theory that says that we need to know something about the world in order to classify it as unknowable. Like the other interpretations, this leaves no room for naturalism, which by definition must be a theory of nature and how it works. Pyrrho does not have one, or need one. If Santayana has one, then he is not a consistent Pyrrhonist.

\footnotetext{
25 Eusebius of Ceasarea (1903), pp. 758-760.

26 Cf. Bett (2000), pp. 63-94 and Conche (1994), p. 44.

27 Eusebius of Caesarea (1903), p. 758.
} 
Santayana recognizes Academic scepticism only in order to refute its claims to thorough-going scepticism. At the end of Skepticism and Animal Faith he argues that "if we assert that one thing is more probable than another, as did the sceptics of the Academy, we have adopted a definite belief, we profess to have some hold on the nature of things at large" (SF308). This can be understood as what he calls animal faith: "this belief in nature, with a little experience and good sense to fill in the picture, is almost enough by way of belief. Nor can a man honestly believe less" (SF308). That means that his interpretation of Academic scepticism makes it similar to his own animal faith; both are dogmatic about something.

Santayana observes that the more dogmatic a scepticism is, the more it tends toward nihilism. A really thorough-going scepticism is "driven back to a nihilism which only silence and death could express consistently" (SF168). He also argues that "total dogmatic scepticism is evidently an impossible attitude" and then adds that "I must revise the premisses of this nihilism" (SF171). Nevertheless, his own scepticism tends toward a nihilism close to Parmenides or Gorgias, rather than toward the sceptics. ${ }^{28}$ Some of the dogmatic, decisive, and radical expressions that we have reviewed above seem to express such nihilism. As we have seen, chapter 7 of Scepticism and Animal Faith is titled "Nothing given exists", a positive declaration that is rather close to the first thesis of Gorgias's "On Non-being", which is that "nothing exists". ${ }^{29}$ Santayana's intention is to prepare the way for the Realm of Matter (physics or perhaps psychology), but this Realm, open only to animal faith, according to Santayana, "would not concern the sceptic", who only attacks claims to truth and knowledge (SF42).

For Santayana reality was rotten; he looked at it with aversion; he was angry with it - all of which drove him to hold it at a distance and suspend judgment about it, even in his youth. ${ }^{30}$ Having determined to turn his back on reality, Santayana employed scepticism as nihilism to justify his radical thesis, his flight to essences. If reality and existence are profoundly ugly and unjust, then beauty may only be found in the imagination. Thus his scepticism as nihilism is limited in scope, a point of departure for the recovery of the Realms of Being. It is not that the indetermina-

\footnotetext{
28 A conventional definition of nihilism would hold that it is a philosophical doctrine that denies the possibility of knowledge, the reality of truth and of moral, social, or political values, and asserts that life has no meaning. See Cassedy (2005), vol. 4, p. 1640. Nihilism has often been confused with scepticism or cynicism. We draw its meaning here from the pre-Socratic Gorgias. A useful study is Calvo (2007), pp. 159-188.

29 Sextus Empiricus wrote that "Gorgias of Leontini... tries to establish successively three main points-firstly, that nothing exists; secondly, that even if something exists it is inapprehensible by man; thirdly, that even if anything is apprehensible, yet of a surety it is inexpressible and incommunicable to one's neighbor". Sextus Empiricus (1935), p. 35.

30 PP166. His youthful idea that "existence was profoundly ugly and wrong" did not change with the passage of time.
} 
tion and indifference or confusion of the world lead him to doubt the reality that surrounds us, but rather the lack of beauty in the world brings him to reject it. He seems to have participated in a certain vital and moral pessimism in certain philosophical circles of the beginning of the twentieth century that led to an almost transcendental desperation that, in the absence of religion, had devastating consequences.

Santayana's response was a pessimism about the capacity of philosophy, a desperation about reason and rationality. One could say that Santayana repeated the pattern of the Spanish classic, Life is a Dream, by Calderón de la Barca. ${ }^{31}$ A kind of fatalism marked the character of the Spanish-American philosopher, who observed that there were no advantages or benefits in the real world, and that all is vanity. ${ }^{32}$ Life is a dream and all of the impressions of experience are illusions (SF51,61).

Santayana's nihilism has been the subject of controversy. Daniel Moreno argues that it is not a destructive nihilism as believed by Luis Farré, nor a "courteous, conservative nihilism" provoked by the First World War, as asserted by A. Woodward, but an "ironic nihilism", "without stridency nor in the service of anything, aristocratic". ${ }^{33}$ This is a nihilism inherited, according to Moreno, from Socratic irony. 34 If there is something to be said for this interpretation in its broadest outlines, it seems to overlook the point that there is more than "splendid isolation" in Scepticism and Animal Faith. 35 There is a desire for philosophical destruction, a strong critique of reality and of all that exists which is closer to Gorgias's radical nihilism than to Pyrrhonian scepticism. Santayana distances himself from the tentativeness, self-confessed lack of surety, and interpretive honesty of the sceptics, making it seem like his professed scepticism is more of a pose in the process of uncovering the truth, rather than a stance that really confronts the weakness of knowledge and the diversity of morals. ${ }^{36}$ It is negative about truth, and yet confident in that negative judgment.

Thus Santayana's "scepticism" is often dogmatic, often closer to nihilism, not derived from a confrontation with equipollent conflicts between things and ideas like that of the ancients. If we are right, the title of Santayana's book might better have been Nihilism and Animal Faith. In the catalogue of scepticisms, Santayana's

\footnotetext{
31 “QQué es la vida? Un frenesí./ ¿Qué es la vida? Una ilusión,/ una sombra, una ficción,/ y el mayor bien es pequeño;/ que toda la vida es sueño,/ y los sueños, sueños son”. Calderón de la Barca (1968), p. 74.

32 This idea was developed by Christian preachers, according to Santayana (SF297).

33 Moreno (2007), pp. 27-36, esp. p. 30. See Farré (1953), p. 79. Woodward (1988), p. 121.

34 Moreno (2007), pp. 30-31.

35 Ibidem.

36 Irving Singer calls this attitude a "heuristic pose", suggesting that the scepticism of Santayana is a stage on the way to the faith of animal nature. See Singer (2000), p. 19. Angel M. Faerna argues that Santayana's purposes are speculative in Faerna (2007), p. 60.
} 
should be understood as oscillating among Academic scepticism, Pyrrhonian scepticism, and a dogmatic, nihilistic scepticism. 37

Santayana does not dare to go as far as some of the ancient sceptics. Faced with the void, he vacillates. Instead of continuing along the path of thorough-going scepticism, as uncomfortable and disagreeable as it might have been, he breaks with it. He declares with disquieting lucidity that "physics and theology, to which most philosophies are confined, are dubious in their first principles", but then he backs away, weakly hoping to save something: "which is not to say that nothing in them is credible" (SF308). Without presenting any argument he decides that life and philosophical discussion require us to avoid this philosophical suicide. It is his epistemological impatience, surely of moral derivation, that makes him pull back from his own confession, at the beginning of the book, where he had said that "I stand in philosophy exactly where I stand in daily life; I should not be honest otherwise. I accept the same miscellaneous witnesses, bow to the same obvious facts, make conjectures no less instinctively, and admit the same encircling ignorance" (SFvi).

"Among the Greek sceptics there were noble minds", Santayana asserted (SF308). ${ }^{38}$ But he was not consistently sceptical. As he put it, "I have imitated the Greek sceptics in calling doubtful everything that, in spite of common sense, any one can possibly doubt... [but] life and even discussion forces me to break away from a complete scepticism" (SF308). Thus, he believed "in discourse, in experience, in substance, in truth, and in spirit. All these objects may conceivably be illusory. Belief in them, however, is not grounded on a prior probability, but all judgments of probability are grounded on them. They express a rational instinct or instinctive reason" (SF308). Santayana accused William James, Josiah Royce, and others of something he called "the genteel tradition in American philosophy". 39 The point was that although they were philosophers claiming to search for the truth, they always pulled back from the edge of materialism and atheism, saving the moral and religious pieties of New England Protestant gentlemen. Santayana's own version of gentility seems to have been to pull back from the edge of a thorough-going scepticism, even if that meant indulging in nihilism. From the point of view of a consistent sceptic, this failure of nerve deserves a line from a play: "he is not worthy of the honey-comb, That shuns the hives because the bees have stings". 40

\footnotetext{
37 Oscar L. González-Castán observes that "scepticism is not inconsistent with animal faith because the sceptic sketched by Santayana has never relieved himself of common beliefs [that is, has never really been a sceptic]", which is yet another proof that Santayana's "scepticism" is actually a dogmatism: González-Castán (2012), pp. 96-97.

38 This passage is confused in the first Spanish translation, Santayana (2002b) [orig. 1952]), where "sceptics" is translated as "sofistas [sophists]" (p. 355) and "Protagoras" is translated as "Pitágoras" twice (p. 353). These errors are corrected in the new translation, Santayana (2012), pp. 353-355.

39 Santayana (2009), passim.

40 "Let come what will, I mean to bear it out, And either live with glorious victorie, Or die with fame
} 


\section{Epicureanism, materialism, cynicism, Spinozism, and the escape from reality}

William Ray Dennes drew attention long ago to Santayana's Epicureanism, and Roger Kimball also wrote of his Epicureanism and its goal of ataraxia. ${ }^{41}$ In a letter, Santayana wrote that "I seem to hold my own in the world without faith, and almost without the world...I have the Epicurean contentment, which was not far removed from asceticism". 42 In Persons and Places he wrote that "Epicurus renounced most of the things called pleasures, for the sake of peace, equanimity, and intelligence", and this could stand for a representation of Santayana himself (PP259). Satisfaction with the here and now, which he cultivated, he also described as "Epicurean contentment in being an accident in an accident" (PP411). And he wrote of his "progress in the primrose path of Epicurean wisdom" (PP426). Thus there is some justification of reading Santayana as oscillating among being a sceptic, a nihilist, and an Epicurean. Each of the latter two are aspects of what he called "animal faith": what we think and live by without philosophical warrant.

Epicureanism is also often understood as a materialism, and Santayana claimed that at the age of seven or eight "I was already a calm materialist" (PP122). He repeated many times, as we have already seen, that "in natural philosophy I am a decided materialist" (SFvii). ${ }^{43}$ In Persons and Places he wrote that he had "made the authority of things, as against the presumption of words or ideas, a principle of my philosophy" and referred to people who thought like him as "we materialists" (PP18). He described his materialism as a "constant sense of the animal basis of spirit" and "disrespect for any claim on the part of spirit to govern the world" (PP387). Materialism meant never dreaming "of rebelling against the despotism of nature" (PP392).

Santayana did not hesitate to attack the philosophy of his times. He made the point that humans always move within perspectives: we glimpse the world of truth, we think we know what it is in itself but we cannot really capture it, we can only make approximations. ${ }^{44}$ Thus he despaired at the dogmatists, the vainglorious, and the petulant who thought they had found the truth for all times and places. And he

renown'd for Chivalrie: He is not worthy of the honey-comb, That shuns the hives because the bees have stings", Shakespeare (1734), Act III, Scene III, p. 1095. The attribution to Shakespeare is false; it has also been attributed to Wentworth Smith. But the point remains.

41 Dennes (1951) p. 437; Kimball (2009), p. 189.

42 Santayana (2002), vol. 5, III, 297.

43 On Epicurean materialism, see Román (2002), pp 77 ff.

44 "That standard comprehensive description of any fact which neither I nor any man can ever wholly repeat, is the truth about it" (SF266). A few years earlier José Ortega y Gasset published Meditaciones del Quijote (1914), in which he claimed for the first time that every truth is a truth from a perspective, valid only from that perspective, and complementing other perspectives: Ortega y Gasset (1914), pp. 35-45. 
rejected the pragmatists, with William James at their head, who insisted that they could identify the value of items of knowledge for human life. Santayana rarely worried about the consequences of action; his interests were in the speculative and aesthetic realm, isolated from practice. He sought a viewpoint above good and bad, above the preferences and evaluations of most people in daily life, in short, a viewpoint from a distance. Thus he insisted against the pragmatists that thought is not essentially instrumental or in service of other goals, but an experience and activity in and for itself. It has its own laws of movement, and is not always trying to serve our practical goals. This impotence for the purpose of achieving goals and truth obliges him to remain at a distance from everything, observing but making no judgment, in a kind of epoché or suspension of judgment which is not so much an epistemological or moral experience as an aesthetic experience. ${ }^{45}$ This seems consistent with Epicureanism.

At times, Santayana reads more like an ancient cynic than an Epicurean or a sceptic. Recall that he described his own position as "like... the ancient Cynics or Sceptics, with a little Epicureanism to soften it". 46 Diogenes the Cynic spent most of his time denouncing the moral failings of the society around him, while refusing to take part as an active citizen. ${ }^{47} \mathrm{He}$ went into the forum or the theater when everyone else was leaving it, to make the point that one should not follow the herd. He belonged to no party or group or team. He called himself a cosmopolites, or citizen of the world. Diogenes lived austerely and simply so that he could live independently. A lot of this can be said for Santayana. He also called himself "a materialist, cynic, and Tory in philosophy", although, as always, this did not imply any effort to closely follow the tradition of cynicism (PP392). Unlike Diogenes, he was a writer and a philosopher. But he was one who maintained his distance and detachment from the people and the society around him, criticizing them mostly in print.

Some of Santayana's philosophy may be of Spinozistic inspiration. Spinoza is one of the few philosophers cited throughout Santayana's work with great respect. A recent interpretation of Spinoza's philosophy as the project of renaturalization sounds like it could be applied to Santayana. 48 As Van Meter Ames put it, "here is Spinoza's teaching that everything happens according to the ways of nature... and that [people] should cherish a private liberty apart from state control". 49 The point

\footnotetext{
45 Cf. Santayana (1905), pp. 205-235, esp. 213-214: "Thought is essentially practical in the sense that but for thought no motion would be an action, no change a progress; but thought is in no way instrumental or servile; it is an experience realised, not a force to be used".

46 Lind (1962), pp. 24, 15.

47 See Laursen (2009), pp. 469-482.

48 Sharp (2011). See what Santayana says about Spinoza in Santayana (2009), pp. 4, 12, 23, 29, 39, 69-71; Santayana (1923), pp. viii, 16, 179, 365; Santayana (1951), p. 18 (and possibly also p. 137, where he refers to one of Spinoza's key concepts, natura naturans).

49 Ames (1952), p. 208.
} 
of both philosophers is that if we really understand nature, human nature, and the way of the world, we get used to the idea that things happen as they do by nature, and they do not faze us. We can remain emotionally calm in the face of everything that nature does, and we try to stay below the radar of the state. This is not ancient sceptical ataraxia based on suspension of judgment, but a sort of ataraxia drawn from reflections on nature and government. This is yet another reason to recognize Santayana's philosophical distance from the ancient sceptics.

It may be suggested that Santayana distanced himself from Spinoza from time to time. In Persons and Places he writes that "in spite of my profound attachment to his system of nature, I miss in his moral sentiment precisely that Castilian disdain and independence, that pagan lust and love of beauty" that Santayana attributed to his Spanish blood (PP12). Despite his usual preference for withdrawal, he rejects Spinoza's consent "to be led to pasture in fat meadows beside the still waters. Quietness and personal frugality I love, but only in the shadow of historic greatness and monumental grandeur of the will" (PP12). This expresses very well Santayana's preference for limiting his emotionalism to his intellectual life. As he put it later, "the complete moralist must not only be sound in physics, but must be inwardly inspired by a normal human soul and an adequate human tradition": "Spinoza was not a complete humanist. He had no idea of human greatness and no sympathy with human sorrow" (PP235). This echoes a charge often made against Santayana, and from his response to it we see that beneath the still waters of his emotional detachment he did indeed believe that he had some attachments. But once again he backed off from that commitment: "content, like Spinoza, with my small share of [a Zion of "fugitive joys and sincere ecstasies"], I dislike all the quarrels and panaceas of the political moralists" (PP502). What he seems to have liked best about Spinoza was his commitment to philosophical liberty. 50

\section{The politics of divided loyalties}

Our review of Santayana's philosophical scepticism, nihilism, Epicureanism, materialism, cynicism, and Spinozism prepares us for reading his politics. In Dominations and Powers, Santayana described the ancient philosophers as "scattered into sects politically either archaistic, with Plato, or indifferent with the Cynics, Sceptics, and Epicureans, or with the Stoics and Neo-Pythagoreans intellectual or mystical worshippers of the rational order of the cosmos" (337). It is pretty clear where he stood among the ancient positions: some form of "indifferent". The themes we have seen of distance, detachment, withdrawal, and failure to take a

50 See Anderson (2009), pp. 9-17. 
stand in Santayana's philosophy may be found in his political writings as well. Yet another way of reading his scepticism is to emphasize his "divided loyalties", as recently expressed by Carlin Romano. 51

Let us start with Santayana's reaction to a political event that one might have thought would be among the most likely to spark the passions of a Spaniard living in the United States: the Spanish American War of 1898-99. As he recounts it in his autobiography, William James was indignant about the American takeover of the Philippines, but Santayana had no strong feelings about it. As one commentator puts it, he was "never excessively impassioned"; he was detached, resigned, dispassionate about the war; he limited himself to understanding it, and he also critically analyzed the posture of the anti-war intellectuals like William James as unrealistic moralizing. 52 One of his poems from those years, "The Pessimist", begins with "I set my heart on politics; I glowed for honesty and freedom", but eventually falls back on a repeated stanza: "I set my heart on nothing now". 53 In his autobiography he observes that the aggressions of the strong are just what we should expect from human behavior since the beginning of time, and that he was undisturbed by this pathetic war (PP402-405). In the contemporary study of international relations, Santayana would be categorized as a realist.

Santayana's big book about politics, Dominations and Powers, was published in 1951, although some of the materials in it had been drafted many years earlier. What is perhaps surprising is that although Santayana spent the World War II years in Rome, very little is said in the book about World War II, the Nazis, or the Soviet Union. What is said is very abstract and very compressed. For example, a reference to "the moral chaos through which the world is now passing" (DP158) could refer to the war, but it may refer to other things. More obvious, but still distanced from the passions of the war, is his analysis of militarization: "Recent wars have shown us,", he observes, "how easily the moral function of industry can be transformed... when great works and whole populations have been turned from manufacturing locomotives and motor-cars to manufacturing bombing aeroplanes and tanks" (DP177). A lesson of "two general wars on an unprecedented scale" is that "the intellectual and political world [are] bewildered" (DP246). Really? Is that all that can be said?

Santayana's next comment on the two world wars is to blame them (and communism) on the ideas of the ancient Greeks and Romans, the Bible, and German philosophy: "Only recently, the two German wars and the sudden Russian threat of universal domination have proved that the classic tradition, passing through the German philosophy of history, drawn from the Bible, inspired the Russian

\footnotetext{
51 Romano (2012), p. 83.

52 See also García Martín (2002), pp. 134, 135, 137, 141.

53 Santayana (1901), pp. 180-181.
} 
Revolution and guides, most unexpectedly, a militant art of government intended to dominate the world" (DP274). This is a view of history at its most distant, abstract, and general. One can hardly blame the Nazis or the communists if they represent such broad currents of intellectual history, and one is prompted to ask if any western intellectual current escapes influence from the classics, the Bible, and German philosophy. It is also probably impossible to confirm or refute history seen in such broad strokes. Later, Santayana refers to WWII as a "terrible sequel" to WWI (DP279), and complains about the post-colonial wars after the "general war of 1939-1945" (DP323). He observes that the peoples of northern Europe are not really very different from each other, which makes their "recent and terrible battles seem unintelligible" (DP365). But these scattered remarks are not much attention to the major wars of his day.

Things get more complicated when we try to understand Santayana's politics, such as it was, in terms of the main ideologies. In his talks with Lind, he described himself as a "conservative" and even as a "Tory". 54 And yet as early as 1934 he was speculating that "the Soviets might be better fitted than any other power to become the guardians of universal peace". 55 This was because they could fill several desiderata: they were "theoretically international" and "we are all born proletarians"; because they believe in Historical Materialism they explicitly recognized "the physical basis of society" [Santayana's materialism]; and they have an "irresistible armed force" (DP455). These were important to Santayana because he thought "real power", by which he clearly meant military power, would be necessary to create a world state (DP455). But he also hoped that the Soviets would not interfere in people's "education, religion, manners, and art": "all culture in the German sense of this word, must be left to free associations" (DP455). This seems rather naïve. Reliance on free associations is perhaps one of the defining differences between liberalism and both communism and fascism. But whether this was a realistic assessment of what the Soviets would have done if they came to power as the world government is perhaps beside the point. What it indicates is that Santayana was by no means a "conservative" as that term is conventionally understood.

Santayana was accused of being both communist and fascist, in part because of the sympathetic things he said about each of these movements at certain points, and in part because of his criticism of modern constitutional democracy. Taking the latter first, he pointed out at some length in Dominations and Powers that modern liberalism really means rule by an oligarchy: rule by the people is only by some of the people (DP398). He reminded people that rule "of the people" can be read two ways: "of" in the sense of "by" and "of" in the sense of "over" (DP396). But this sort of criticism of liberalism has been made by thinkers whose liberal credentials

54 Lind (1962), pp. 55, 68. See also his description of himself as a "tory" in philosophy (PP392).

55 Chapters 40 and 41 of Book Third of Dominations and Powers were initially published in 1934. 
are not usually questioned: Kant said that democracy is rule by all, or not quite all. ${ }^{56}$ We hesitate to call this an immanent critique, however, because Santayana did his best to not appear to be arguing from inside anything. His favorable comments on some aspects of fascism, for example that in Italy it was in part a religious movement, did not mean that he was endorsing it, and certainly not from inside. ${ }^{57}$ When he said he was not too worried about the communists, that was because he thought that their efforts to change human nature and extinguish selfishness would "wither away" of their own accord in the ordinary course of life (DP254). Despite some tentative positives, most of what he says in Dominations and Powers about communism is negative (e.g.DP366, 399, 411). It represents the militant order of things, in contrast to the healthy generative order (DP427, 457). He was, as we have insisted throughout, always detached and distant, perhaps especially in politics. As he told Lind, "I've never kept in touch with politics". 58

One of the paradoxes of Santayana's politics is that despite his disclaimers he did have some emotional and personal impulses in politics, but they can be understood to run in the opposite direction from his philosophy. James Seaton has done a nice job of showing that several of his letters express sympathy for Franco and Mussolini, whereas a reading of his contrasts between the "generative" and "militant" orders in Dominations and Powers implies a rejection of both communism and fascism in favor of what he elsewhere referred to as "English liberty". ${ }^{59}$ It is almost as if his natural way of thinking and doing was always to argue, emote, and see both sides of every issue, which would add to his sceptical credentials.

Some people have believed that the fact that Santayana never returned to the United States after 1912 suggests that he repudiated the country, its people, or its politics. And he certainly never refrained from criticizing the naiveté, the hypocrisy, the consumerism that could be found there. But on the whole his attitude is quite positive. The pages on the United States in "Character and Opinion in the United States" of 1920 reflect admiration for the optimism and energy of the people, even if he did not share them. Some of the last pages of Dominations and Powers describe the American government as a potential leader of a universal jurisdiction (DP458). In part, this is because "the American people are good" (DP458). He adds that the government might not be self-restrained enough to avoid imposing much more control on the world than it should, but perhaps that is not a surprising criticism (DP459). His last sentence is the rather optimistic speculation that America might "turn from devising machines to cultivating liberal arts and enlarging moral freedom" (DP461). Given his life-long penchant for distancing himself from the

\footnotetext{
56 Kant (1991), p. 101.

57 Lind (1962), p. 113.

58 Lind (1962), p. 143.

${ }^{59}$ Seaton (2009), pp. 81-100.
} 
things he cared about, it could be argued that one of the reasons that Santayana never returned to the United States was that he loved it too much.

Throughout his last book, Santayana is never fazed, never rushed, never saddened. It is always a view from afar, maybe far above, with Olympian detachment. It confirms the idea that he was consistent in both philosophy and politics in maintaining emotional distance. He was never a close follower of any school of philosophy or politics, and perhaps is best understood as a true eclectic. A picture of Santayana's philosophy or politics will almost inevitably be a collage, such as we have put together in this article. On the whole, he improvised his own philosophy, and we have noted that he pulled back from the brink of following through on all of the implications of scepticism, never took much of a stand in politics, and so forth. The implications that he seems to have carried out with some thoroughness are those of the philosophical life as he led it. In the search for ataraxia he seems to have found that distance, emotional coolness, reluctance to commit himself, and the like were some of his most effective tools. A sceptical smile may well have been the most emotion he would ever express in matters of philosophy or politics (SF9). ${ }^{60}$ Thus he was able to write many books, live in many places, and yet never really take on the emotional commitments that more involved writers and philosophers have held. He criticized the professional philosophers for their isolation from the world, but he seems to have managed to live in an ivory tower himself.

\section{Bibliography}

Anderson, D. (2009): "Santayana and Spinoza on Philosophic Liberty", Overheard in Seville: Bulletin of the George Santayana Society 27, pp. 9-17.

AmES, V. M. (1952): "The Zenith as Ideal”, The Journal of Philosophy 49, pp. 201208.

Aulus Gellius (1948-1952): The Attic Nights of Aulus Gellius, trans. J. C. Rolfe, Cambridge, Harvard University Press.

BetT, R. (2000): Pyrrho, his Antecedents and his Legacy, New York, Oxford University Press.

Calderón de la Barca, P. (1968): La Vida es Sueño, Jornada Segunda, ed. Augusto Cortina, Madrid, Espasa Calpe.

Calogero, G. (1932): Studi sull' Eleatismo, Rome, La Nuova Italia.

CAlvo, T. (2007): "De Parménides a Gorgias: el mundo verdadero como fábula" in

Pensar la nada: ensayos sobre filosofia y nihilismo, Madrid, Biblioteca Nueva. CASSEDY, S. (2005): "Nihilism", in New Dictionary of the History of Ideas, ed. M. Horowitz, New York, Scribner's, vol. 4, pp. 1638-1641.

60 See Cejudo and Román (2012), pp. 119-137. 
Cejudo, R. and Román, R. (2012): "Ideologías y escepticismo en George Santayana", Contrastes. Revista Internacional de Filosofia 17, pp. 119-137.

Cicero, Academica, tr. Rackham, H. (1933): Cambridge, Harvard University Press. Conche, M. (1994): Pyrrhon ou l'apparence, Paris, PUF.

DeNNES, W. R. (1951): "Santayana's materialism" in Schilpp (1951), pp. 417-443.

Diogenes Laertius (1925): Lives of Eminent Philosophers, trans. R. D. Hicks, Cambridge, Harvard University Press.

DupréEL, E. (1948): Les Sofistes, Paris, P.U.F.

EusEBIUS of Cesarea (1903): Praeparatio Evangelica, trans. E. H. Gifford, Oxford, Oxford University Press.

FAERNA, A. M. (2007): "Instrucciones para arrojar una escalera (Wittgenstein y Santayana sobre el escepticismo)", Limbo 27, pp. 55-69.

FARRÉ, L. (1953): Vida y pensamiento de Jorge de Santayana, Madrid, Cisneros.

GARCÍA MARTín, P. (2002): "Jorge de Santayana y los acontecimientos de 1898", Teorema, 21, pp. 133-143.

GónZÁLEZ-CASTÁN, O.L. (2012): "Santayana: La difícil tarea de recuperar la fe animal desde el escepticismo", Limbo 32, pp. 75-98.

Hadot, P. (1995): Philosophy as a Way of Life, Oxford, Blackwell.

IzuzQuiza, I. (1989): George Santayana o la ironía de la material, Barcelona, Anthropos.

Kant, I. (1991): Perpetual Peace (1795) in Kant: Political Writings, ed. H. Reiss, Cambridge, Cambridge University Press, pp. 93-130.

Kimball, R. (2009): "Mental Hygiene and Good Manners" in Santayana (2009), pp. 175-192.

LACHS, J. (1988): George Santayana, Boston, Twayne.

LARreA, A. (2013): "La pluma del olvido: Santayana literato" en George Santayana: un español en el mundo, ed. Manuel Bermúdez, Sevilla, Espuela de Plata, pp. 182-211.

Laursen, J. C. (2004): "Yes, Skeptics Can Live Their Skepticism and Cope with Tyranny as Well as Anyone" in Maia Neto, J. and Popkin, R. eds., Skepticism in Renaissance and Post-Renaissance Thought, Amherst, N.Y.: Humanity Books / Books Series of the Journal of the History of Philosophy, pp. 201-223.

LAURSEN, J. C. (2005): "Oakeshott's Skepticism and the Skeptical Traditions", European Journal of Political Theory 4, pp. 37-55.

Laursen, J. C. (2005): "Skepticism, Unconvincing Anti-skepticism, and Politics" in Scepticisme et modernité, eds. Marc André Bernier and Sébastien Charles, Saint-Étienne, Publications de l'Université de Saint-Étienne, pp. 167-188.

Laursen, J. C. (2009): "Cynicism Then and Now", Iris: European Journal of Philosophy and Public Debate 1, pp. 469-482. 
Lind, B. (1962): Vagabond Scholar: A Venture into the Privacy of George Santayana, New York, Bridgehead Books.

Long, A. A. and Sedley, D. N. eds. (1987): The Hellenistic Philosophers, Cambridge, Cambridge University Press.

Maia Neto, J. and Popkin, R. (2004) eds., Skepticism in Renaissance and PostRenaissance Thought, Amherst, N.Y.: Humanity Books / Books Series of the Journal of the History of Philosophy.

McClay, W. M. (2009): "The Unclaimed Legacy of George Santayana", in Santayana (2009), pp. 123-147.

McCormick, J. (1987): Santayana: A Biography, New York, Knopf.

Moreno, D. (2007): Santayana filósofo: la filosofia como forma de vida, Madrid, Trotta.

Nehamas, A. (1998): The Art of Living: Socratic Reflections from Plato to Foucault, Princeton, Princeton University Press.

Ortega y Gasset, J. (1914): Meditaciones del Quijote, Madrid, Publicaciones de la Residencia de Estudiantes.

RomÁN, R. (2002): Lucrecio: razón filosófica contra superstición religiosa, Córdoba, UNED.

RomÁn, R. (2005): "El escepticismo antiguo: Pirrón de Elis y la indiferencia como terapia de la filosofía", Daimon: Revista de Filosofia 36, pp. 35-51.

Román, R. (2007): El enigma de la Academia de Platón: escépticos contra dogmáticos en la Grecia Clásica, Córdoba, Berenice.

RomÁn, R. (2012): "La invención de una escuela escéptica pirrónica”, Revista de Filosofía 37, pp. 111-130.

RomÁn, R. and Cejudo, R. (2012): "Ideologías y escepticismo en George Santayana", Contrastes. Revista Internacional de Filosofía 17, pp. 119-137.

Romano, C. (2012): America the Philosophical, New York, Knopf.

Santayana, G. (1901): A Hermit of Carmel, London, Fisher Unwin.

Santayana, G. (1905): Reason in Common Sense, New York, Scribner's.

Santayana, G. (1923): Scepticism and Animal Faith: Introduction to a System of Philosophy, New York, Scribner's.

Santayana, G. (1951): Dominations and Powers: Reflections on Liberty, Society, and Government, New York, Scribner's.

Santayana, G. (1986): Persons and Places: Fragments of Autobiography, eds. W. Holzberger and H. Saatkamp, Cambridge, MIT Press.

Santayana, G. (2002): The Letters of George Santayana, eds. W. Holzberger and H. Saatkamp, Cambridge, MIT Press.

SANTAYANa, G. (2002b): Escepticismo y fe animal. Introducción a un sistema de filosofia, trans. R. Piérola and M. Rosemberg, Oviedo, Losada. 
Santayana, G. (2009): The Genteel Tradition in American Philosophy and Character and Opinion in the United States, ed. James Seaton, New Haven, Yale University Press.

SANTAYANA, G. (2011): Escepticismo y fe animal. Introducción a un sistema de filosofia, trans. A. M. Faerna, Madrid, Antonio Machado libros.

Schilpp, P. A., ed. (1951): The Philosophy of George Santayana, New York, Tudor Publishing Company.

Seaton, J. (2009): "Introduction" to Santayana (2009), pp. xi-xxxviii.

SEATon, J. (2009): "Santayana on Fascism and English Liberty", Limbo 29, pp. 81100.

Sextus Empiricus (1933): Outlines of Pyrrhonism, tr. R. G. Bury, Cambridge, Harvard University Press.

Sextus Empiricus (1936): Against the Ethicists, tr. R. G. Bury, Cambridge, Harvard University Press.

SeXtus Empiricus (1935): Against the Logicians, tr. R. G. Bury, Cambridge, Harvard University Press.

Shakespeare, W. (1734): The Tragedy of Locrine, the eldest son of King Brutus, London, Tonson.

ShARP, H. (2011): Spinoza and the Politics of Renaturalization, Chicago, University of Chicago Press.

Singer, I. (2000): George Santayana, Literary Philosopher, New Haven, Yale University Press.

Sullivan, C. J. (1951): "Santayana's Philosophical Inheritance" in Schilpp (1951), pp. 63-92.

Woodward, A. (1988): Living in the Eternal: A Study of George Santayana, Nashville, Vanderbilt University Press.

John Christian Laursen

University of California, Riverside

john.laursen@ucr.edu

Ramón Román Alcalá

Facultad de Filosofía y Letras

Universidad de Córdoba

fs1roalr@uco.es 